\title{
ANALISIS DAMPAK PENGHENTIAN TUGAS KPA KOTA YOGYAKARTA BERDASARKAN PERATURAN PRESIDEN NOMOR 124 TAHUN 2016
}

\author{
Gerry Katon Mahendra \\ Universitas Aisyiyah Yogyakarta \\ Daerah Istimewa Yogyakarta, Indonesia \\ gerrykatonvw@gmail.com
}

\begin{abstract}
ABSTRAK
Kasus HIV AIDS di Kota Yogyakarta mengalami kecenderungan naik setiap tahunnya. Namun disaat yang bersamaan, pemerintah pusat membubakaran beberapa Lembaga Non Struktural (LNS) yang dianggap tidak efektif. Melalui Peraturan Presiden No.124/2016 pasal 17a ayat 1 pemerintah pusat resmi menghentikan tugas Komisi Penanggulangan AIDS Nasional (KPAN) per 31 Desember 2017. Hal ini tentu saja berimbas kepada KPA Daerah seluruh Indonesia, termasuk KPA Kota Yogyakarta. Disaat mereka giat dan gencar melakukan upaya meminimalisir penyebaran HIV AIDS hingga menorehkan prestasi. Hal tersebut pada akhirnya menimbulkan dampak yang cukup signifikan dalam upaya meminimalisir penyebaran HIV AIDS, diantaranya pengalihan tanggung jawab penanggulangan HIV AIDS dan sudut pandang penanganan HIV AIDS, potensi kekurangan SDM ASN dalam upaya penanggulangan HIV AIDS, dan perubahan pola koordinasi penanggulangan HIV AIDS.
\end{abstract}

Kata Kunci : Kebijakan Publik, Komisi Penanggulanan AIDS, PP Nomor 124 Tahun 2016.

\section{ABSTRACT}

HIV-AIDS cases in the city of Yogyakarta have an upward trend every year. But at the same time, the central government burned down several Non-Structural Institutions (LNS) which were deemed ineffective. Through Presidential Regulation No.124 / 2016 article 17a paragraph 1, the central government officially terminated the duties of the National AIDS Commission (KPAN) as of December 31, 2017. This of course had an impact on Regional KPAs throughout Indonesia, including the Yogyakarta City KPA. While they are active and aggressively making efforts to minimize the spread of HIV-AIDS, they have made achievements. This in turn has a significant impact in the effort to minimize the spread of HIV AIDS, including the transfer of responsibility for HIV AIDS prevention and the point of view of handling HIV AIDS, potential shortages of ASN human resources in the effort to combat HIV AIDS, and changes in coordination patterns of HIV AIDS response.

Keywords: Public Policy, AIDS Prevention Commission, Government Regulation Number 124 Year 2016.

\section{PENDAHULUAN}

Kasus Human Immunodeficiency Virus dan Acquired Immune Deficiency Syndrome (HIVAIDS) di Indonesia selama ini mengalami tren meningkat tiap tahunnya. Melalui data Kemenkes yang dikutip oleh Spiritia.or.id (2016) menyatakan bahwa mulai tahun 2005 saja sudah teridentifikasi sebanyak 859 kasus HIV AIDS, tahun 2006 (7.195 kasus), tahun 2007 (6.048 kasus), tahun 2008 (10.362 kasus), tahun 2009 (9.793 kasus), tahun 2010 (21.591 kasus), tahun 2011 (21.031 kasus), tahun 2012 (21.511 kasus), tahun 2013 (29.037 kasus), tahun 2014 (32.711 kasus), tahun 2015 (30.935 kasus), dan tahun 2016 (41.250 kasus). Menurut Diyan Purnomo (2015) HIV AIDS merupakan permasalahan ekstrim yang secara mudah berpindah sehingga secara geografis dan sosial tidak tetap hingga saat ini, kemudahan berpindah tempat atau berubah arah merupakan gambaran global dari virus tersebut. Oleh karena itu, dibutuhkan sebuah strategi dari berbagai pihak untuk mengurangi dan menanggulangi penyebaran virus mematikan ini. Semakin meningkatnya kasus 
HIV-AIDS di Indonesia kemudian direspon oleh pemerintah pusat dengan membentuk Komisi Penanggulangan AIDS Nasional (KPAN) melalui Peraturan Presiden Nomor 75 Tahun 2006 Tentang Komisi Penanggulangan AIDS. Dasar normatif tersebut kemudian berturut-turut diperkuat melalui Peraturan Menteri Dalam Negeri Nomor 20 Tahun 2007 Tentang Pedoman Umum Pembentukan Komisi Penanggulangan HIV dan AIDS dan Pemberdayaan Masyarakat dalam rangka Penanggulangan HIV AIDS di Daerah, dan Instruksi Menteri Dalam Negeri Nomor 444.24 / 2259 / SJ Tahun 2013 Tentang Penguatan Kelembagaan dan Pemberdayaan Masyarakat dalam Penanggulangan AIDS di Daerah. KPAN juga memiliki perwakilan di daerah, baik tingkat provinsi maupun kabupaten/kota dengan nomenklatur Komisi Penanggulangan AIDS Daerah dengan berlandaskan peraturan daerah tersebut. Secara umum tugas pokok dan fungsi dari Komisi Penanggulangan AIDS adalah menetapkan kebijakan dan rencana strategis nasional serta pedoman umum pencegahan, pengendalian, dan penanggulangan AIDS; Menetapkan langkah-langkah strategis yang diperlukan dalam pelaksanaan kegiatan; Mengkoordinasikan pelaksanaan kegiatan penyuluhan, pencegahan, pelayanan, pemantauan, pengendalian, dan penanggulangan AIDS; Melakukan penyebarluasan informasi mengenai AIDS kepada berbagai media massa, dalam kaitan dengan pemberitaan yang tepat dan tidak menimbulkan keresahan masyarakat; Melakukan kerjasama regional dan internasional dalam rangka pencegahan dan penanggulangan AIDS; Mengkoordinasikan pengelolaan data dan informasi yang terkait dengan masalah AIDS; Mengendalikan, memantau, dan mengevaluasi pelaksanaan pencegahan, pengendalian, dan penanggulangan AIDS; Memberikan arahan kepada Komisi Penanggulangan AIDS Provinsi dan Kabupaten/Kota dalam rangka pencegahan, pengendalian, dan penanggulangan AIDS. Dengan serangkaian tugas pokok fungsi tersebut, KPAN maupun KPAD diharapkan mampu bersinergi dengan lembaga-lembaga lain dalam upaya memberikan edukasi dan meminimalisir penyebaran virus HIV AIDS di wilayah Indonesia. Namun, disaat wabah penyebaran HIV AIDS di Indonesia semakin meningkat dan KPAD sedang bersinergi dengan berbagai organisasi perangkat daerah (OPD) dan lembaga swadaya lainnya, pemerintah membuat keputusan untuk membubarkan beberapa lembaga non struktural (LNS), yang salah satunya adalah Komisi Penanggulangan AIDS. Pembubaran tersebut tertuang dalam Peraturan Presiden Nomor 124 tahun 2016 pasal 17a yang berbunyi; Ayat 1 : Komisi Penanggulangan AIDS Nasional menyelesaikan tugasnya paling lambat tanggal 31 Desember 2017. Ayat 3: Dengan berakhirnya masa tugas Komisi Penanggulangan AIDS Nasional sebagaimana dimaksud pada ayat (1), segala aset Komisi Penanggulangan AIDS Nasional menjadi aset milik negara yang selanjutnya diserahkan kepada kementerian yang menyelenggarakan urusan pemerintahan di bidang kesehatan setelah dilakukan audit sesuai dengan ketentuan peraturan perundang-undangan.

Pembubaran tersebut tentu saja berdampak bagi KPA yang ada di seluruh wilayah Indonesia, tidak terkecuali di Kota Yogyakarta. Selama ini Wilayah Kota Yogyakarta dikenal sebagai destinasi wisata dan pendidikan bagi banyak kalangan. Hal ini tentu saja membuat intensitas interaksi antar manusia di Kota Yogyakarta sangat tinggi. Salah satu dampak dari hal tersebut tentu saja peluang penyebaran virus HIV AIDS yang semakin besar. Data Komisi Penanggulangan AIDS (KPA) Kota Yogyakarta menunjukkan hingga Maret 2015 tercatat terdapat 831 kasus HIV-AIDS. Jumlah tersebut meningkat cukup signifikan dari jumlah total kasus di 2014 sebanyak 802 kasus dan 2013 ada 677 kasus serta pada 2012 tercatat 566 kasus. Dari data tersebut, sebanyak 37 persen diantaranya menjangkiti masyarakat usia produktif (Republika, 2015). Kasus-kasus tersebut selama ini ditangani oleh KPA Kota Yogyakarta bekerjasama dengan organisasi perangkat daerah(OPD) dan LSM terkait guna menekan upaya penyebaran virus HIV AIDS. Langkah tersebut dinilai cukup membuahkan hasil, salah satunya bukti torehan prestasi penghargaan dari KPA Pusat kepada KPA Kota Yogakarta sebagai KPAD terbaik tingkat Kabuapten/Kota se-Jawa Tengah pada tahun 2015. Namun ditengah upaya 
memberantas virus HIV AIDS di wilayah Kota Yogyakarta, keputusan pemerintah pusat untuk membubarkan KPAD dan menempatkan tugas tersebut dibawah bidang pengendalian dan pemberantasan penyakit (P2P) Dinas Kesehatan Kota Yogyakarta tentu memberikan dampak yang signifikan dan merubah program yang selama ini direncanakan maupun yang sudah terlaksana. Berdasarkan tersebut, artikel ini akan mencoba menganalisis dampak penghentian tugas KPA Kota Yogyakarta berdasarkan peraturan Presiden Nomor 124 Tahun 2016 agar dapat mengetahui lebih lanjut dampak tersebut.

Penelitian yang dilakukan oleh Siti Wahyuningsih dan kawan-kawan (2017) berjudul Implementasi Kebijakan Pencegahan Dan Penanggulangan Human Immunodeficiency/Aquired Immune Deficiency Syndrome (Hiv/Aids) Di Kota Surakarta. Hasil dari penelitian tersebut adalah banyak faktor yang menjadi penyebab belum maksimalnya penanggulangan HIV dan AIDS, diantaranya adalah masalah HIV dan AIDS belum dianggap masalah prioritas baik oleh sektor kesehatan maupun sektor pembangunan yang terkait; dukungan politik yang belum memadai terhadap program; belum terkordinasinya Komisi Penanggulangan AIDS (KPA) dan SKPD Kota Surakarta; masih belum maksimalnya penyebaran dan akses informasi layanan kesehatan dan ketersediaan adanya layanan VCT, ARV bagi penderita dan orang beresiko tinggi terinfeksi HIV dan AIDS. Penelitian yang dilakukan oleh Diyan Purnomo dan kawan-kawan (2015) berjudul Analisis Kebijakan Penanggulangan Hiv Dan Aids Di Kabupaten Malang. Hasil penelitian tersebut adalah kebijakan penanggulangan HIV dan AIDS di Kabupaten Malang sudah dijalankan sesuai tujuan dari pembuatan kebijakan yang tercantum dalam Peraturan Daerah. Keterlibatan stakeholder dalam setiap proses kebijakan menunjukkan hubungan kerjasama yang baik antara pemerintah dengan LSM (Lembaga Swadaya Masyarakat), dan masyarakat. Hasil peneletian ini juga menunjukkan adanya faktor-faktor yang menjadikan dukungan dan kendala dalam implementasi kebijakan ini.

\section{Perubahan Organisasi}

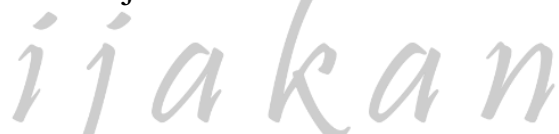

Wibowo (2007) menyatakan bahwa terdapat tiga macam tipe perubahan organisasi yang dinamakan dengan development change, transitional change dan trasformational change. Development change menggambarkan perubahan melalui perubahan keterampilan, metode, standar kinerja atau kondisi yang telah ada. Terdapat dua asumsi yaitu orang mampu memperbaki serta mereka akan menjadi lebih baik apabila diberi alasan, sumber daya, motivasi dan pelatihan yang tepat. Transitional change merupakan respon pada pergeseran signifikan pada kekuatan lingkungan atau kebutuhan pasar untuk sukses. Transformational change merupakan pergeseran yang radikal dari satu keadaan ke keadaan lainnya sehingga signifikan apabila memerlukan pergeseran budaya, perilaku dan pola pikir agar berlangsung sukses dan berlangsung sepanjang waktu. Berdasarkan konsep tersebut, penghentian tugas KPA Kota Yogyakarta dapat dikategorikan dalam transitional change dimana penghentian KPA Kota Yogyakarta didasari pada respon terhadap lingkungan dan kebutuhan pemerintah maupun masyarakat. pemerintah menilai KPA sebagai salah satu lembaga non struktural (LSN) memiliki kinerja yang kurang efektif, sehingga demi menghemat anggaran tugas dari KPA terpaksa dihentikan dan dialihkan melalui lembaga lain. Winardi (2010) menyatakan, bahwa perubahan organisasi adalah tindakan beralihnya sesuatu organisasi dari kondisi yang berlaku kini menuju ke kondisi masa yang akan datang menurut yang di inginkan guna meningkatkan efektivitasnya. Robbin dan Coulter (2012) mengemukakan bahwa Perubahan organisasional yakni setiap perubahan yang terkait dengan orang, struktur atau teknologi. Struktur organisasi merupakan suatu cara pembagian tugas pekerjaan yang kemudian dikelompokkan serta dikoordinasikan secara 
formal. Robbins (2010) mengemukakan 6 (enam) unsur yang perlu diperhatikan dalam pembentukan suatu struktur organisasi, yaitu: Spesialisasi, Departementalisasi, Rantai Komando, Rantai Kendali, Sentralisasi, dan Formalisasi. Pasca dihentikannya tugas dari KPA Kota Yogyakarta, segala bentuk tugas pokok fungsinya kemudian dialihkan dan menjadi tanggung jawab dari bidang P2P Dinas Kesehatan Kota Yogyakarta. Artinya dalam hal ini terdapat perubahan struktur yang bersifat sentralisasi dengan tujuan dan harapan agar tugas pokok fungsinya dapat berjalan lebih terkontrol dan efektif.

\section{Hiv Aids}

Human Immunodeficiency Virus (HIV) merupakan retrovirus yaitu virus yang mempunyai enzim revese transkriptase yang memungkinkan virus ini untuk mengubah informasi genetiknya yang berada dalam ribonukleat (RNA) ke dalam bentuk deoksibonukleat (DNA) (Widyanto dan Triwibowo, 2013). Hasil dari perubahan ini akan diintegrasikan ke dalam informasi genetik sel limfosit yang diserang kemudian memanfaatkan mekanisme sel limfosit untuk menggandakan dirinya menjadi virus baru yang memiliki ciri seperti HIV (Widyanto dan Triwibowo, 2013). AIDS adalah sekumpulan gejala dan infeksi (atau sindrom) yang timbul karena rusaknya sistem kekebalan tubuh manusia akibat virus $\mathrm{HIV}$; atau infeksi virus-virus lain yang mirip yang menyerang spesies lainnya (SIV, FIV, dan lainlain) (Syafrudin dkk, 2011). Kaitannya dengan tulisan ini adalah virus HIV AIDS merupakan virus menular yang dapat membahayakan kesehatan dan jiwa seseorang. Dampak bahaya dari virus tersebut sudah menjadi perhatian oleh pemerintah, baik pusat maupun daerah khususnya pemerintah Kota Yogyakartas. Upaya-upaya terstruktur sudah dilakukan oleh pemerintah guna meminimilisir penyebaran virus tersebut.

\section{METODE}

Penelitian kualitatif menurut Moleong (2007) merupakan penelitian yang bermaksud untuk memahami fenomena tentang apa yang dialami oleh subjek penelitian misalnya perilaku, persepsi, motivasi, tindakan, dan lain-lain, secara holistik, dan dengan cara deskripsi dalam bentuk kata-kata dan bahasa, pada suatu konteks khusus yang alamiah dan dengan memanfaatkan berbagai metode alamiah.Dalam artikel ini subjek penelitian atau informan merupakan pihak yang berkompeten dan mengetahui permasalahan penelitian. Penentuan informan dalam penelitian kualitatif berfungsi untuk mendapatkan informasi yang maksimum dengan mempertimbangkan hal-hal tertentu seperti dianggap paling tahu tentang apa yang diharapkan atau mengehatui secara jelas yang dapat memudahkan peneliti (Sugiyono, 2013). Teknik pengumpulan data kualitatif menurut Sugiyono (2009) bahwa pengumpulan data dapat diperoleh dari hasil observasi, wawancara, dokumentasi, dan gabungan/triangulasi. Teknik pengumpulan data dengan cara wawancara dan dokumentasi. Wawancara dilakukan dengan mengajukan pertanyaan kepada narasumber/informan terkait dengan penghentian tugas KPA Kota Yogyakarta. Dokumentasi dilakukan dengan mengumpulkan data pendukung (arsip dokumen, buku) yang berkaitan penghentian tugas KPA Kota Yogyakarta. Teknik analisis data dalam penelitian ini merujuk pada teori yang dikemukakan oleh Huberman dan Miles dalam Idrus (2009) yang mengajukan model analisis data yang disebut dengan model interaktif. Model interaktif terdiri dari tiga hal utama, yaitu:

a. Reduksi data merupakan langkah awal dalam menganalisa data dalam penelitian ini. Dalam penelitian ini, aspek-aspek yang direduksi adalah hasil wawancara maupun dokumentasi.

b. Penyajian data (display) merupakan tahapan kedua dari tiga tahapan aktivitas menganalisa data dalam penelitian kualitatif. 
c. Penarikan kesimpulan dan verifikasi merupakan bagian ketiga dalam teknik analisa data pada penelitian. Dari berbagai aktivitas yang telah dilakukan sebelumnya, penulis membuat kesimpulan berdasarkan data-data yang telah dikumpulkan.

\section{PEMBAHASAN}

Komisi Penanggulangan AIDS di Kota Yogyakarta dibentuk berdasarkan Peraturan Walikota Yogyakarta Nomor 106 Tahun 2016 tentang penanggulangan HIV dan AIDS. KPA Kota Yogyakarta terletak Jalan Kenari No.56, Muja Muju, Umbulharjo, Kota Yogyakarta, Daerah Istimewa Yogyakarta 55165. Sebelum diberhentikan tugasnya berdasarkan Peraturan Presiden Nomor 124 tahun 2016, KPA Kota Yogyakarta memiliki tugas utama yakni melakukan upaya koordinasi dengan Dinas/SKPD terkait, terutama Dinas Kesehatan Kota Yogyakarta terkait dengan penanganan dan penanggulangan AIDS di Kota Yogyakarta. Fokus KPA Kota Yogyakarta lebih kepada koordinasi, sosialisasi, dan pemberdayaan. Namun semenjak disahkannya Peraturan Presiden Nomor 124 tahun 2016 Tentang Perubahan Atas Peraturan Presiden Nomor 75 Tahun 2006 Tentang Komisi Penanggulangan Aids Nasional KPA Kota Yogyakarta harus mengakhiri tugasnya maksimal per 31 Desember 2017, sebagaimana tertuang dalam Pasal 17A dan Pasal 17B. Hal tersebut tentu menimbulkan beberapa dampak terkait penanggulangan HIV AIDS. Dampak pertama, setelah berakhirnya masa tugas Komisi Penanggulangan AIDS Kota Yogyakarta sebagaimana dimaksud tertuang dalam peraturan tersebut, tugas dan fungsi KPA yang berupa penetapan kebijakan, rencana strategis daerah, dan langkahlangkah strategis, penyebarluasan informasi, kerja sama, serta pengendalian, pemantauan, dan evaluasi yang dilaksanakan oleh Komisi Penanggulangan AIDS Kota Yogyakarta menjadi tanggung jawab dinas kesehatan dibawah bidang P2P. Sejalan dengan pernyataan Winardi (2010) bahwa perubahan organisasi adalah tindakan beralihnya sesuatu organisasi dari kondisi yang berlaku kini menuju ke kondisi masa yang akan datang menurut yang di inginkan guna meningkatkan efektivitasnya. Perubahan tersebut pada akhirnya tentu memiliki dampak terhadap kelancaran tugas pokok fungsi lembaga dalam menanggulangi penyebaran HIV AIDS. Hal ini kemudian menimbulkan kekhawatiran dari pihak yang peduli dengan HIV AIDS. Dengan dilimpahkannya urusan penanggulangan HIV AIDS kepada Dinas Kesehatan, khususnya bidang P2P muncul kekhawatiran nantinya proses penanggulangan HIV AIDS dilaksanakan hanya melalui sudut pandang kesehatan saja. Padahal perlu diketahui bahwa sebelumnya melalui KPA Kota Yogyakarta, proses penanggulangan HIV AIDS dilakukan bersama-sama dengan OPD non kesehatan seperti Dinas Sosial dan Dinas Perhubungan dan memperhatikan aspek-aspek penting, seperti aspek sosial, budaya, ekonomi, disamping aspek kesehatan. Hal tersebut penting karena HIV AIDS tersebut tidak semata-mata karena faktor kesehatan, namun banyak faktor lain yang turut memiliki andil.

Dampak kedua, dengan dilimpahkannya tanggung jawab kebidang P2P Dinas Kesehatan berarti sumber daya manusia didalam lembaga tersebut akan memiliki tanggung jawab lebih berat karena mendapatkan limpahan tugas dari KPA Kota Yogyakarta. Sebagaimana pernyataan yang terdapat dalam jurnal Siti Wahyuningsih (2017) bahwa keberadaan peraturan dan kebijakan yang tidak dibarengi dengan ketersediaan sumber daya yang kompeten, sehingga peraturan dan kebijakan itu tidak memberikan nilai lebih dalam. Selama ini masalah keterbatasan SDM cukup sering ditemui, utamanya terkait keterbatasan jumlah SDM ASN di lembaga pemerintah daerah. Sedangkan penanggulangan HIV AIDS selama ini membutuhkan SDM yang tidak sedikit dan upaya dengan tingkat intensitas yang tinggi serta kompetensi yang mumpuni. Hal tersebut sebelumnya dapat terkondisikan karena pegawai yang berada di KPA Kota Yogyakarta merupakan pegawai non ASN yang memang khusus direkrut untuk menjalankan tugas di lembaga tersebut. sejak keluarnya Peraturan Presiden terbaru, otomatis mereka pun dibebastugaskan dari KPA Kota Yogyakarta. 
Dampak ketiga, terkait dengan penghentian KPA Kota Yogyakarta adalah kegiatan koordinasi dan pelaksanaan program penanggulangan HIV AIDS. Disatu sisi, secara normatif tugas KPA Kota Yogyakarta berakhir per 31 Desember 2017, namun fakta di lapangan menyebutkan bahwa segala bentuk koordinasi dan pelaksanaan program, utamanya pada awal tahun 2018 masih melibatkan lembaga KPA Kota Yogyakarta. Hal tersebut tentu saja menjadi kerancuan bagi KPA Kota Yogyakarta maupun OPD yang terlibat dalam koordinasi dan pelaksanaan program penanggulangan HIV AIDS. Contoh kerancuan sederhana misalnya terkait surat undangan koordinasi, siapa yang harus mengundang dan siapa yang menandatangani surat tersebut.

Terkait dengan kehadiran Peraturan Presiden Nomor 124 tahun 2016 sebenarnya perlu ada dorongan untuk segera dikeluarkannya Permenkes. Mengapa demikian? Permenkes tersebut diharapkan dapat menjadi dasar bagi kepentingan berbagai pihak terkait dengan penanggulan HIV AIDS yang melibatkan OPD lainnya, sehingga penanggulangan HIV AIDS di Kota Yogyakarta nantinya tidak hanya menjadi ranah kesehatan saja. Terlepas dari pro kontra Peraturan Presiden Nomor 124 tahun 2016, upaya penanggulangan HIV AIDS tetap harus menjadi perhatian serius pemerintah, baik pusat maupun daerah karena Indonesia sampai hari ini belum bisa terbebas dari virus mematikan tersebut. Bahkan berdasarkan data United Nations Programme on HIV and AIDS (UNAIDS), sampai Desember 2016 saja di Indonesia tercatat sebanyak 690 ribu penduduk yang terinfeksi HIV, dengan hanya 30\% saja diantaranya yang mengetahui dirinya terjangkit virus tersebut.

\section{KESIMPULAN}

Berdasarkan pembahasan diatas dapat disimpulkan bahwa dengan terbitnya Peraturan Presiden Nomor 124 tahun 2016 secara langsung berdampak pada penanggulangan HIV AIDS di Kota Yogyakarta. Dampak yang timbul diantaranya terkait dengan pengalihan tanggung jawab penanggulangan HIV AIDS dan sudut pandang penanganan HIV AIDS, potensi kekurangan SDM ASN dalam upaya penanggulangan HIV AIDS, dan perubahan pola koordinasi penanggulangan HIV AIDS. Saran yang dapat diberikan penulis dalam penelitian ini antara lain :Menyikapi perubahan peraturan dengan tetap mengedepankan prinsip profesionalitas dan prinsip kualitas pelayanan bagi penderita HIV AIDS di Kota Yogyakarta;

1. Melalui stakeholders terkait, sekiranya dapat mendorong pemerintah untuk dapat meninjau kembali Peraturan Presiden Nomor 124 Tahun 2016, khususnya pasal 17 A dan pasal 17 B serta membuat peraturan turunan yang tujuannya mendukung penanggulangan HIV AIDS secara maksimal;

2. Memaksimalkan upaya yang sudah berjalan dan merekonstruksi rencana dimasa yang akan datang terkait dengan penanggulangan HIV AIDS di Kota Yogyakarta;

3. Melibatkan peran serta masyarakat dalam upaya penanggulangan HIV AIDS di Kota Yogyakarta.

\section{DAFTAR PUSTAKA}

Idrus, Muhammad. 2009. Metode Penelitian Ilmu Sosial, Pendekatan Kualitatif Dan Kuantitatif Edisi Kedua. Jakarta: Erlangga.

Moleong, Lexy J. 2007. Metodologi Penelitian Kualitatif. Bandung: PT Remaja Rosdakarya Offset.

Robbins, Stephen P. 2010. Perilaku Organisasi (Organizational Behavior). Terj: Diana Angelica Buku 1 dan 2. Jakarta: Salemba Empat.

Robbins, Stephen P. and Coulter, Mary. 2012. Management. New Jersey: Pearson Education, Inc

Sugiyono. 2013. Metode Penelitian Pendidikan (Pendekatan Kuantitatif, Kualitatif, dan R\&D). Bandung: Alfabeta 
Sugiyono. 2009. Metode Penelitian Bisnis (Pendekatan Kuantitatif, Kualitatif, dan R\&D). Bandung: Alfabeta.

Syafrudin. 2011. Penyuluhan Kesehatan Pada Remaja, Keluarga, Lansia dan Masyarakat. Jakarta: Trans Info Media.

Wibowo. 2007. Manajemen Perubahan. Jakarta: PT. Raja Grafindo Persada.

Widyanto, F. C dan Triwibowo, C. 2013. Trend Disease Trend Penyakit Saat Ini. Jakarta: Trans Info Media

Winardi J. 2010. Manajemen Perubahan. Jakarta: Kecana Prenada Media Group

Purnomo, Diyan., Saleh Soeaidy, Muhammad., \& Hadi, Minto. (2015). Analisis Kebijakan Penanggulangan Hiv Dan Aids Di Kabupaten Malang. Jurnal Administrasi Publik (JAP), Vol. 3, No. 1, Hal. 42-48.

Wahyuningsih, Siti., Tresno Novianto, Widodo., \& Purwadi, Hadi. (2017). Implementasi Kebijakan Pencegahan Dan Penanggulangan Human Immunodeficiency/Aquired Immune Deficiency Syndrome (Hiv/Aids) Di Kota Surakarta. Jurnal Pasca Sarjana Hukum UNS Volume V Nomor 2 Juli-Desember 2017.

Republika.co.id (2015). Jumlah Pengidap HIV/AIDS di Yogya Terus Meningkat. Diperoleh tanggal 3 Agustus 2017 dari http://nasional.republika.co.id/berita/nasional/daerah/15/11/10/nxk67k346jumlah-pengidap-hivaids-di-yogya-terus-meningkat

Spiritia.or.id (2016). Laporan Situasi Perkembangan HIV/AIDS dan PIMS s.d. Desember 2016. Diperoleh tanggal 3 Agustus 2017 dari. http://spiritia.or.id/Stats/detailstat.php?no=8

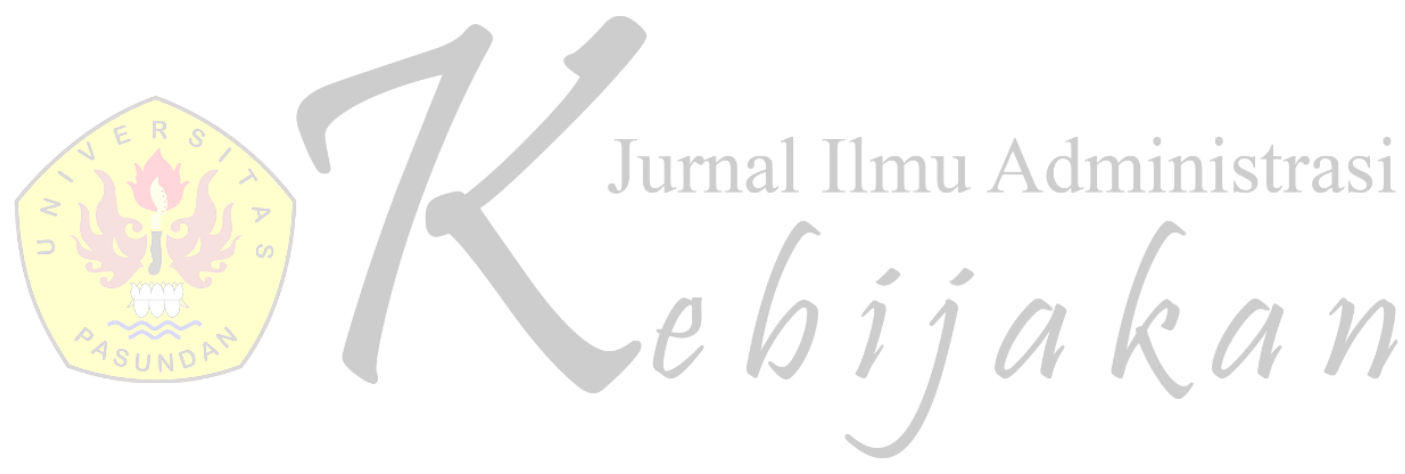

